\title{
Colchicine in COVID-19: an Old Drug, New Use
}

\author{
Naomi Schlesinger ${ }^{1} \cdot$ Bonnie L. Firestein ${ }^{2} \cdot$ Luigi Brunetti $^{3}$ \\ Published online: 18 July 2020 \\ (C) Springer Nature Switzerland AG 2020
}

\begin{abstract}
Purpose of Review Coronavirus disease 2019 (COVID-19), caused by severe acute respiratory syndrome-coronavirus-2 (SARS-CoV-2) infection, is a pandemic causing havoc globally. Currently, there are no Food and Drug Administration (FDA)-approved drugs to treat COVID-19. In the absence of effective treatment, off-label drug use, in lieu of evidence from published randomized, double-blind, placebo-controlled clinical trials, is common in COVID-19. Although it is vital to treat affected patients with antiviral drugs, there is a knowledge gap regarding the use of anti-inflammatory drugs in these patients.

Recent Findings Colchicine trials to combat inflammation in COVID-19 patients have not received much attention. We await the results of ongoing colchicine randomized controlled trials in COVID-19, evaluating colchicine's efficacy in treating COVID-19.

Summary This review gives a spotlight on colchicine's anti-inflammatory and antiviral properties and why colchicine may help fight COVID-19. This review summarizes colchicine's mechanism of action via the tubulin-colchicine complex. Furthermore, it discussed how colchicine interferes with several inflammatory pathways, including inhibition of neutrophil chemotaxis, adhesion, and mobilization; disruption of superoxide production, inflammasome inhibition, and tumor necrosis factor reduction; and its possible antiviral properties. In addition, colchicine dosing and pharmacokinetics, as well as drug interactions and how they relate to ongoing, colchicine in COVID-19 clinical trials, are examined.
\end{abstract}

Keywords Colchicine $\cdot$ Colchicine-tubulin complex $\cdot$ Anti-inflammatory $\cdot$ COVID-19 $\cdot$ SARS-CoV-2 infection $\cdot$ Antiviral

\section{Introduction}

Coronavirus disease 2019 (COVID-19), caused by severe acute respiratory syndrome-coronavirus-2 (SARS-CoV-2) infection, is a pandemic causing havoc globally. Currently, there are no Food and Drug Administration (FDA)-approved drugs to treat COVID-19. Off-label drug use, in lieu of evidence

This article is part of the Topical Collection on Covid-19

Naomi Schlesinger

schlesna@rutgers.edu

1 Division of Rheumatology, Department of Medicine, Rutgers Robert Wood Johnson Medical School, New Brunswick, NJ 08903-0019, USA

2 Department of Cell Biology and Neuroscience, Rutgers, The State University of New Jersey, Piscataway, NJ 08854-8082, USA

3 Department of Pharmacy Practice and Administration, Ernest Mario School of Pharmacy, Rutgers, The State University of New Jersey, New Brunswick, NJ, USA from published randomized, double-blind, placebocontrolled clinical trials, is common in COVID- 19. Although it is vital to treat affected patients with antiviral drugs, there is a knowledge gap regarding the use of antiinflammatory drugs in these patients.

One critical question is which anti-inflammatory drugs are most appropriate. At present, there is insufficient clinical data to recommend either for or against the use of chloroquine, hydroxychloroquine, convalescent plasma, hyperimmune immunoglobulin, interleukin-6 inhibitors (e.g., sarilumab, siltuximab, tocilizumab), interleukin-1 inhibitors (e.g., anakinra), except in the context of a clinical trial (https:// www.idsociety.org/covid19guidelines; https:// covid19treatmentguidelines.nih.gov/therapeutic-optionsunder-investigation/).

Colchicine, made from preparations of the meadow saffron Colchicum autumnale, has been used for over 2000 years as a poison and as a remedy for gout flares [1]. However, the full configuration of colchicine was determined only in 1955 when it was identified as a neutral lipophilic tricyclic alkaloid, the main features of 
which include a trimethoxyphenyl ring, a 7-membered ring with an acetamide at the seven position, and a tropolonic ring [2] (Fig. 1).

Colchicine for oral use (capsule/tablet/liquid) is currently FDA approved for the prevention and treatment of gout flares in adults with gout and Familial Mediterranean fever (FMF) (https://www.fda.gov/drugs/postmarket-drugsafety-information-patients-and-providers/colchicinemarketed-colcrys-information). Off-label uses for colchicine are many and include acute calcium pyrophosphate (CPP) arthritis (pseudogout), sarcoid and psoriatic arthritis, Behcet's disease, and pericarditis, and recently, studies have shown colchicine's efficacy in preventing major cardiovascular adverse events among patients who suffered a recent myocardial infarction [3].

Despite over 2000 years of use, new therapeutic uses of colchicine, beyond gout [4], are being explored. Colchicine trials to combat inflammation in COVID-19 patients have not received much attention. Currently, ten colchicine clinical trials are in progress for the treatment of SARS-CoV-2 infection and are listed in clinicaltrials. gov (https://clinicaltrials.gov/ct2/results?cond= COVID $\&$ term $=$ colchicine $\&$ cntry $=\&$ state $=\&$ city $=\&$ dist $=$ ) (Table 1).

This review gives a spotlight on colchicine's antiinflammatory and antiviral properties and why colchicine may help fight COVID-19. This review summarizes colchicine's mechanism of action via the tubulincolchicine complex. Furthermore, it discussed how colchicine interferes with several inflammatory pathways, including inhibition of neutrophil chemotaxis, adhesion, and mobilization; disruption of superoxide production, inflammasome inhibition, and tumor necrosis factor reduction; and its possible antiviral properties. In addition, colchicine dosing and pharmacokinetics, as well as drug interactions and how they relate to ongoing, colchicine in COVID-19 clinical trials, are examined.

\section{Colchicine's Mechanism of Action}

\section{Tubulin-Colchicine Complex}

Colchicine is an inhibitor of mitosis and microtubule assembly. It binds to soluble, non-polymerized tubulin heterodimers to form a tight tubulin-colchicine complex [5]. At lower doses, colchicine interferes with microtubule formation and elongation, and at higher doses, colchicine promotes microtubule depolymerization [6] (Fig. 1). Furthermore, the polymerization of colchicine-bound tubulin occurs in a manner closely related to microtubule assembly, resulting in a polymer with different morphology, causing a distortion in normal tubulin polymerization and microtubule generation [7]. Since microtubules are involved in a variety of cellular processes, such as cell division, maintenance of cell shape, cell signaling, signal transduction, cell migration, and cellular transport, colchicine can inhibit these functions as well as neutrophil chemotaxis.

Colchicine binds not only to tubulin but also to leukocyte membrane proteins that often provide sites for attachment of microtubules and consequent cytoskeletal reorganization [8]. However, most of the anti-inflammatory effects of colchicine are likely due to the disruption of microtubule function; hence, cells with high proliferative rates are disproportionately affected by colchicine [5]. Furthermore, inhibition of ameboid

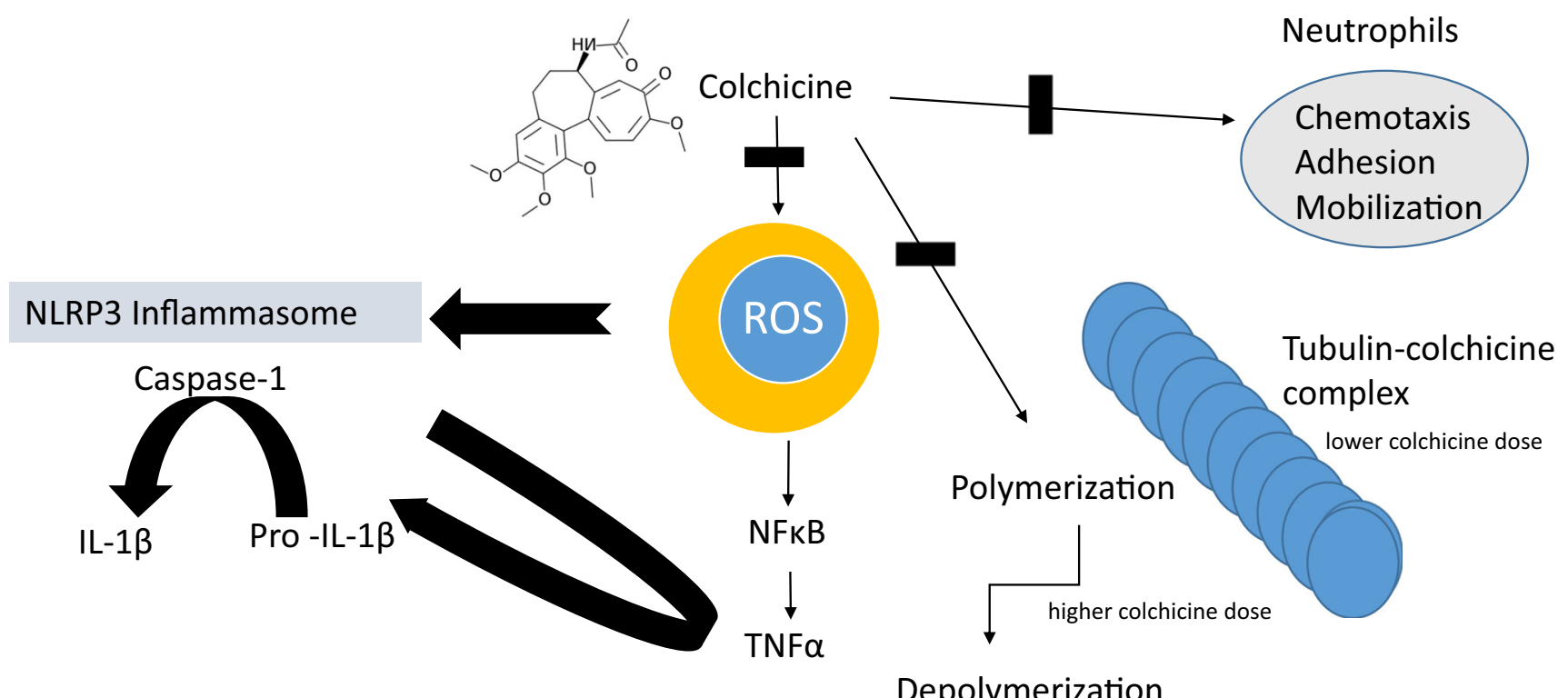

Fig. 1 Colchicine is anti-inflammatory 
Table 1 Registered clinical trials investigating colchicine in COVID-19 infection

Study Design $\quad$ Country $\quad$ Target Colchicine dose $\quad$ Setting Primary outcome
enrollment

COLHEART-19/NCT04355143

COLCOVID/NCT04328480

NCT04360980

COL-COVID/NCT04350320

COLCORONA/NCT04322682

ColchiVID/NCT04367168

$\begin{array}{ccc}\text { Randomized, open } & \text { United } & 150 \\ \text { label clinical trial } & \text { Stated } & \\ \text { Randomized, open } & \text { Argentina } & 2500 \\ \text { label clinical trial } & & \end{array}$

label clinical trial
$0.6 \mathrm{mg}$ every $12 \mathrm{~h}$ for
30 days

In patients

lopinavir/ritonavir,

loading dose of

$1.5 \mathrm{mg}$ followed by

$0.5 \mathrm{mg}$ after $2 \mathrm{~h}$ (day

$1)$; then next day

$0.5 \mathrm{mg}$ bid for

14 days or until

discharge.

In patients receiving lopinavir/ritonavir, loading dose of $0.5 \mathrm{mg}$ (day 1); after

$72 \mathrm{~h}$ from the loading dose, $0.5 \mathrm{mg}$ every $72 \mathrm{~h}$ for 14 days or until discharge.

In patients under treatment with colchicine that are starting with lopinavir/ritonavir; dose of $0.5 \mathrm{mg} 72 \mathrm{~h}$ after starting lopinavir/ritonavir; continue with $0.5 \mathrm{mg}$ every $72 \mathrm{~h}$ for 14 days or until discharge.

$\begin{array}{cccc}\begin{array}{c}\text { Randomized, } \\ \text { double-blind } \\ \text { clinical trial }\end{array} & \text { Iran } & 80 & \begin{array}{c}1.5 \mathrm{mg} \text { loading dose } \\ \text { then } 0.5 \mathrm{mg} \text { twice } \\ \text { daily }\end{array}\end{array}$
Randomized, open Spain
label clinical trial

102

Initial dose of $1.5 \mathrm{mg}$ (1 mg and $0.5 \mathrm{mg} 2 \mathrm{~h}$ after), followed by $0.5 \mathrm{mg}$ every $12 \mathrm{~h}$ during the next 7 days and $0.5 \mathrm{mg}$ every $24 \mathrm{~h}$ until the completion of 28 days of total treatment

In patients receiving ritonavir or lopinavir or with reduced renal clearance $(<50 \mathrm{ml} / \mathrm{min} / 1.37$ $\mathrm{m}^{2}$ ), weight $<70 \mathrm{~kg}$ or age $>75$ years old, the dose will be adjusted to the half the first 3 days and

controlled $\quad$ Spain

clinical trial States

Randomized, Mexico
6000

174
Inpatient C-reactive protein $\times$ neutrophil-to-lymphocyte ratio change

Inpatient Changes in the patients' clinical status through the 7 points ordinal scale
$0.5 \mathrm{mg}$ twice daily for then once daily for the last 27 days

\section{Outpatient Number of participants who die or require hospitalization due to COVID-19 infection}

$1.5 \mathrm{mg}$ at day 1 followed Inpatient Number of patients with by $0.5 \mathrm{mg}$ PO twice improvement in body 
Table 1 (continued)

\begin{tabular}{|c|c|c|c|c|c|c|}
\hline Study & Design & Country & $\begin{array}{l}\text { Target } \\
\text { enrollment }\end{array}$ & Colchicine dose & Setting & Primary outcome \\
\hline & $\begin{array}{l}\text { placebo-- } \\
\text { controlled, } \\
\text { double blind } \\
\text { clinical trial }\end{array}$ & & & $\begin{array}{l}\text { daily to complete } \\
10 \text { days of treatment }\end{array}$ & & $\begin{array}{l}\text { temperature, myalgia, } \\
\text { arthralgia, total } \\
\text { lymphocyte count, } \\
\text { D-dimer, fibrinogen } \\
\text { and ferritin levels }\end{array}$ \\
\hline ColCOVID-19/NCT04322565 & $\begin{array}{l}\text { Randomized, open } \\
\text { label clinical trial }\end{array}$ & Italy & 310 & $\begin{array}{l}1 \mathrm{mg} \text { (or } 0.5 \mathrm{mg} \text { in } \\
\text { chronic kidney } \\
\text { disease) per day }\end{array}$ & Inpatient & $\begin{array}{l}\text { Time to clinical } \\
\text { improvement defined } \\
\text { as time from } \\
\text { randomization to an } \\
\text { improvement of two } \\
\text { points from the status at } \\
\text { randomization on a } \\
\text { seven-category } \\
\text { ordinary scale }\end{array}$ \\
\hline COMBATCOVID19/NCT04363437 & $\begin{array}{l}\text { Randomized, open } \\
\text { label clinical trial }\end{array}$ & $\begin{array}{l}\text { United } \\
\text { States }\end{array}$ & 70 & $\begin{array}{l}\text { Starting dose of } 1.2 \mathrm{mg} \\
\text { followed, by } 0.6 \mathrm{mg} \\
\text { after } 2 \mathrm{~h} \text { if they do not } \\
\text { have significant } \\
\text { gastrointestinal } \\
\text { symptoms, on day } 1 . \\
\text { Then, } 0.6 \mathrm{mg} \text { twice a } \\
\text { day for } 14 \text { days or } \\
\text { until discharged or } \\
\text { release from the } \\
\text { hospital }\end{array}$ & Inpatient & $\begin{array}{l}\text { Percentage of Patients } \\
\text { requiring supplemental } \\
\text { oxygen beyond } 81 \\
\text { nasal cannula }\end{array}$ \\
\hline GRECCO-19/NCT04326790 & $\begin{array}{l}\text { Randomized, open } \\
\text { label clinical trial }\end{array}$ & Greece & 180 & $0.5 \mathrm{mg}$ twice daily & N/A & $\begin{array}{l}\text { Clinical deterioration in } \\
\text { the semi-quantitative } \\
\text { ordinal scale }\end{array}$ \\
\hline COLVID-19/NCT04375202 & $\begin{array}{l}\text { Randomized, open } \\
\text { label clinical trial }\end{array}$ & Italy & 308 & $\begin{array}{l}0.5 \mathrm{mg} \text { three times a day } \\
\text { if weight is less than } \\
100 \mathrm{~kg} ; 1 \mathrm{mg} \text { twice a } \\
\text { day if weight is more } \\
\text { than } 100 \mathrm{~kg} \text { for } \\
30 \text { days or up to } \\
\text { discharge }\end{array}$ & Inpatient & $\begin{array}{l}\text { Composite of respiratory } \\
\text { failure requiring } \\
\text { mechanical ventilation; } \\
\text { organ failure requiring } \\
\text { ICU monitoring and } \\
\text { treatment; death }\end{array}$ \\
\hline
\end{tabular}

motility by colchicine prevents disruption of membranedependent functions, such as chemotaxis and phagocytosis [9].

\section{Colchicine Interferes with Several Inflammatory Pathways (Fig. 1)}

The anti-inflammatory effects of colchicine are diverse. Colchicine has an inhibitory effect on neutrophil functions, such as adhesiveness, motility, and degranulation of lysosomes [10], and neutrophil chemotaxis [11]. Colchicine decreases the expression of adhesion molecules on neutrophil membranes, leading to a significant inhibition in migration and interaction with endothelial cells and modulates the production of proinflammatory cytokines, such as interleukin (IL)-1, IL-6, and tumor necrosis factor (TNF)- $\alpha$.

\section{Inhibition of Neutrophil Chemotaxis, Adhesion, and Mobilization}

The concentration of colchicine that accumulates in neutrophils may be more than 16 times the peak concentration observed in plasma [12]. This observation may be due to little or no expression of P-glycoprotein (P-gp), an integral membrane, and adenosine triphosphatase (ATPase) efflux protein in neutrophils [13]. P-gp facilitates the removal of colchicine from cells. Thus, a relative lack of P-gp may allow colchicine to accumulate in neutrophils, helping to explain how colchicine seems to target neutrophils selectively.

In many inflammatory diseases, neutrophils are the primary cells involved in the immune response. The first step in the pathogenesis of inflammation is the adhesion of neutrophils to endothelial cells [14]. Their participation in inflammation depends upon their ability to migrate towards damaged or stimulated tissue [15]. Since neutrophil migration is dependent on 
microtubules, colchicine binding to tubulin distorts this capability, thereby suppressing the inflammatory process. Colchicine dramatically reduces the adhesion of neutrophils to the endothelium. Endothelial cells play a vital role in neutrophil transmigration towards the inflammatory site, and colchicine inhibits stimulation-mediated endothelial adhesiveness via its effects on microtubules. Colchicine interferes with neutrophil-endothelial interactions by altering the number and/or distribution of selectins on endothelial cells and neutrophils and decreases E-selectin-mediated adhesiveness of the cytokine-stimulated vascular endothelium to neutrophils at nano- $\alpha$-prophylaxis [16]. At higher micro-concentrations (IC50 $=300 \mathrm{nM}$ ), colchicine induces the shedding of neutrophil adhesion molecules. In addition, colchicine disrupts microtubule structure and reduces neutrophil elasticity and relaxation, thus preventing neutrophil extravasation from the blood vessels to the site of inflammation. This disruption may be the last and most effective step in inhibiting chemotaxis [17].

\section{Disruption of Superoxide Production}

In the presence of colchicine, peritoneal mouse macrophages show less adenosine triphosphate (ATP)-induced permeability to ethidium bromide and decreased formation of reactive oxygen species (ROS), nitric oxide (NO), and release of IL-1 $\beta$. Colchicine inhibits monosodium urate (MSU)-induced superoxide production by murine peritoneal macrophages in vivo at doses 100 times lower than that required to inhibit neutrophil infiltration [18], suggesting that superoxide anion production may be more sensitive to suppression by colchicine than microtubule formation involved in cell migration. The production of ROS may act as a common event upstream of the NACHT-LRRPYD-containing protein 3 (NLRP3) inflammasome [19], a signaling pathway described below. TNF is a regulator of the generation of ROS, and TNF- $\alpha$ and ROS influence each other in a positive feedback loop.

\section{Inflammasome Inhibition}

A major signaling pathway of the innate immune system is the inflammasome, a multiprotein complex, primarily expressed in monocytes and macrophages, with little expression in other leukocytes or adipocytes [20, 21]. The NLRP3 inflammasome is composed of three distinctive components: NLRP3, an apoptosis-associated speck-like protein containing a CARD (ASC), and caspase-1. Activation of NLRP3 leads to the production of active IL-1 $\beta$ and IL-18. The colchicine-tubulin complex blocks NLRP3 inflammasome formation and activation by inhibiting microtubule polymerization and attenuates macrophage NLRP3 inflammasome arrangement and activation in vitro and in vivo $[22,23]$. This attenuation stems from disruption of microtubule-mediated transport of mitochondria (where endogenous ASC is localized) to the endoplasmic reticulum, where NLRP3 is localized. The co-localization of NLRP3 and ASC is required for assembly and activation of the inflammasome to produce mature IL-1 $\beta$.

While plasma concentration after a single dose of $0.6 \mathrm{mg}$ colchicine is approximately $3 \mathrm{nmol} / \mathrm{L}$, neutrophils can contain levels of 40-200 nmol/L [24]. Although many of the experiments performed in vitro have used larger doses not feasible for use in humans, a standard low dose of colchicine drastically reduces serum levels of inflammasome products and caspase-1 monocyte production [25]. In a mouse myocardial infarct model, at doses equivalent to those used in humans $(0.1 \mathrm{mg} / \mathrm{kg})$, colchicine reduces the expression of NLRP3 inflammasome components in addition to lowering inflammatory mediators $[26,27]$.

\section{Tumor Necrosis Factor Reduction}

Colchicine reduces both the generation of TNF- $\alpha$ by macrophages and its receptors on endothelial cells [28, 29]. Colchicine modulates lipopolysaccharide-induced secretion of TNF- $\alpha$ by liver macrophages in a rat model and downregulates $\mathrm{TNF}-\alpha$ receptors on endothelial cells by $70-75 \%$, resulting in diminished surface expression [28]. Importantly, TNF- $\alpha$ induces nuclear factor kappa-light-chain-enhancer of activated $B$ cells $(\mathrm{NF}-\kappa \mathrm{B})$ activation and the stability of microtubules correlates with the regulation of NF- $\mathrm{KB}$ signaling. Specifically, if microtubules are destabilized by colchicine, the induction of NF- $\mathrm{BB}$ by TNF- $\alpha$ is significantly reduced [29].

\section{Anti-viral Properties of Colchicine}

Tubulin ligands have the potential to inhibit the replication of viruses that depend on the microtubule network. The intracellular transport of viral particles in the host cell, including particle trafficking in later stages of the infection, is mediated by microtubules and associated proteins $[30,31]$. By inhibiting microtubule polymerization, colchicine has been reported to cause a significant decrease in virus replication in flaviviruses, such as dengue and Zika viruses [32]; blocks transport and reduces the replication of recombinant demyelinating strain of the mouse hepatitis virus [33]; inhibits respiratory syncytial virus (RSV) infection in neonatal rats through regulation of anti-oxidative factor production leading to inhibition of RSV replication, thus, leading to a significant reduction in the levels of IL- 6 and TNF- $\alpha$ [34]. In addition, colchicine and colchicine derivatives may influence HIV viral load [35].

Coronaviruses, members of the Nidovirales order, are enveloped, positive-sense, single-stranded RNA viruses, which redirect and rearrange host cell membranes for use as part of the viral genome replication and transcription [35]. Their replication moves in the cell in a manner that 
corresponds to microtubule-associated transport, inducing the formation of double-membrane vesicles in infected cells [36]. The infection of cells by coronaviruses involves the interaction of the cytoplasmic tail of the spike protein with cytoskeletal proteins (i.e., tubulin) [37]. This interaction leads to viral entry. Furthermore, microtubules are involved in the transport and assembly of spike proteins into virions during the replication cycle $[38,39]$. The colchicine-tubulin complex may block viral entry and replication [40]. This hypophysis requires confirmation.

In an animal model of bronchopulmonary dysplasia, colchicine-treated rat pups had decreased lung damage and lower lung concentrations of IL-1 and TNF- $\alpha$, suggesting that this therapeutic will reach the target tissue in COVID-19 [41]. Furthermore, other organs are affected by COVID-19-related inflammation, including the myocytes. Previous studies demonstrate the anti-inflammatory activity of colchicine on the heart $[3,42]$. It has been suggested that SARS-CoV and its accessory protein are potent activators of pro-IL- $1 \beta$ gene transcription and protein maturation, and thus, can activate the NLRP3 inflammasome. Influenza virus M2 or encephalomyocarditis virus (EMCV) $2 \mathrm{~B}$ proteins $2 \mathrm{~B}$ protein stimulate IL- $1 \beta$ secretion following activation of the NLRP3 inflammasome [43]. Importantly, in experimental models of acute respiratory distress syndrome/acute lung injury (ARDS/ALI), the NLRP3 inflammasome plays a significant role in the development of lung injury [44].

In a case report of a COVID-19-infected patient with signs of systemic inflammation, treatment with $1 \mathrm{mg}$ of colchicine on day 8 and $0.5 \mathrm{mg} /$ day after that was reported to be beneficial [45].

\section{Pharmacokinetics}

Colchicine is absorbed in the jejunum and ileum and accumulates in tissues. It is metabolized in the liver and the intestine by cytochrome P (CYP) 450 3A4 and P-glycoprotein (P-gp). The absorption of oral colchicine is rapid but incomplete (time to $\max =2 \mathrm{~h}$; bioavailability $=25-50 \%$ ). However, absorption can be highly variable. The onset of action is approximately $24 \mathrm{~h}$ via the oral route. The half-life of colchicine after an oral dose in patients with normal renal and hepatic functions is $9 \mathrm{~h}$, whereas, in patients with renal failure, it is $2-3$ times the normal length (about $24 \mathrm{~h}$ ). In cirrhotic patients with renal failure, the half-life is 10 times normal (approximately 4 days) $[8,9]$. Colchicine is not removed by conventional hemodialysis and does not penetrate brain tissue, heart muscle, or skeletal muscle.

Cells in different stages of mitosis exhibit distinct sensitivity to colchicine. At a concentration of $50 \mathrm{nM}$, colchicine blocks almost all mitotic cells. A distinctive feature of colchicine is its capacity to accumulate in inflammatory cells, reaching higher concentrations than plasma levels and with markedly longer duration of action [19, 24]. Colchicine is excreted mainly by the biliary system, intestines, and kidneys. The main metabolic pathway for colchicine is deacetylation in the liver, followed by shuttling to enterohepatic circulation before being excreted into the bile (10 to $25 \%$ ) and the feces (10 to $56 \%$ after oral administration) [5]. Urinary excretion is approximately 10 to $20 \%$ of the administered dose. It has been observed that colchicine is still present in the urine as late as 10 days after the administration of a single subtherapeutic dose [22].

In the presence of mild to moderate renal or hepatic impairment, adjustment of dosing is not required, but patients should be monitored closely. In patients with severe renal or hepatic impairment, chronic gout flare prevention or chronic treatment of FMF, the starting dose should be $0.3 \mathrm{mg} /$ day. For patients undergoing dialysis, the total recommended dose for gout flare prevention is $0.3 \mathrm{mg}$ given twice weekly with close monitoring (https://www.fda.gov/drugs/postmarket-drugsafety-information-patients-and-providers/colchicinemarketed-colcrys-information).

\section{Dosing in the Ongoing Clinical Trials}

Colchicine can be administered by mouth as 0.5 or $0.6 \mathrm{mg}$ and up to $1 \mathrm{mg}$ in tablets. In 2014, the FDA withdrew approval following several cases of fatal toxicity [46]. For the treatment of gout flares, the FDA-approved dose is $1.2 \mathrm{mg}$ (two tablets) at the first sign of a gout flare followed by $0.6 \mathrm{mg}$ (one tablet) $1 \mathrm{~h}$ later (total $1.8 \mathrm{mg}$ ). For gout flare prevention, the FDAapproved dose is $0.6 \mathrm{mg}$ once or twice daily with a maximum dose of $1.2 \mathrm{mg} /$ day. For Familial Mediterranean Fever (FMF), the dose is up to $1.2-2.4 \mathrm{mg}$ (https://www.fda.gov/drugs/ postmarket-drug-safety-information-patients-and-providers/ colchicine-marketed-colcrys-information).

The oral colchicine dose used in the COVID-19 clinical trials registered on the clinicaltrialsl.gov site varies (https:// clinicaltrials.gov/ct $2 /$ results? cond=COVID \& term $=$ colchicine $\&$ cntry $=\&$ state $=\&$ city $=\&$ dist $=): 0.5 \mathrm{mg}$ twice daily for the first 3 days and then once daily for the last 27 days; 0 . $6 \mathrm{mg}$ by mouth twice daily for 30 days; $0.5 \mathrm{mg}$ twice daily with no time limit; or $1 \mathrm{mg}$ daily for 30 days. Others use a loading dose of $1.2 \mathrm{mg}$ followed by $0.6 \mathrm{mg}$ after $2 \mathrm{~h}$ on day 1 (similar to gout flare treatment) followed by $0.6 \mathrm{mg}$ twice a day for 14 days or until discharged or release from the hospital. Yet, others load with $1.5 \mathrm{mg}(1 \mathrm{mg}$ and $0.5 \mathrm{mg} 2 \mathrm{~h}$ after), followed by $0.5 \mathrm{mg}$ every $12 \mathrm{~h}$ during the next 7 days and $0.5 \mathrm{mg}$ every $24 \mathrm{~h}$ after until the completion of 28 days of total treatment versus two other trials that have the same loading dose of $1.5 \mathrm{mg}$ but follow with a twice-daily dose for 10 days. Yet, another clinical trial has no time limit for the twice-daily dose. Treatment starts in some of these trials as 
early as the time that a patient tests positive for COVID-19 by a PCR-based assay and others only when patients are experiencing cardiac injury or show evidence of cytokine release syndrome.

Only two of the colchicine clinical trials (https:// clinicaltrials.gov/ct $2 /$ results? cond=COVID\&term $=$ colchicine $\&$ cntry $=\&$ state $=\&$ city $=\&$ dist $=$ ) mention altering the colchicine dose in patients receiving lopinavir/ritonavir or other conditions placing patients at risk for toxicity (i.e., advanced age, chronic kidney disease), as described below.

\section{Drug Interactions}

As stated above, colchicine is a P-gp and CYP3A4 substrate. The drugs reported causing colchicine toxicity are P-gp inhibitors [42]. P-gp inhibitors include antacids, such as cimetidine; antibiotics, such as erythromycin and tetracycline; calcium channel blockers, such as diltiazem and verapamil; immunosuppressants, such as cyclosporine and tacrolimus; HIV proteases inhibitors, such as lopinavir and ritonavir; azole antifungals, such as itraconazole and ketoconazole; antiarrhythmic drugs, such as amiodarone, and quinidine; and selective estrogen receptor modulators, such as tamoxifen (https:// www.fda.gov/drugs/postmarket-drug-safety-informationpatients-and-providers/colchicine-marketed-colcrysinformation). Life-threatening and fatal drug interactions have been reported in patients treated with colchicine given with $\mathrm{P}$ gp and potent CYP3A4 inhibitors [42]. If treatment with a Pgp or strong CYP3A4 inhibitor is required in patients with normal renal and hepatic function, the patient's dose of colchicine may need to be reduced or interrupted to prevent toxicity (https://www.fda.gov/drugs/postmarket-drug-safetyinformation-patients-and-providers/colchicine-marketedcolcrys-information). Only two of the colchicine clinical trials (https://clinicaltrials.gov/ct2/results?cond=COVID\&term= colchicine $\&$ cntry $=\&$ state $=\&$ city $=\&$ dist $=)$ address the use of other medications concomitantly with colchicine, which may warrant a decrease in colchicine dosing.

The most common adverse reactions reported in the clinical trial for gout were diarrhea (23\%) and pharyngolaryngeal pain (3\%). The most common adverse reactions for FMF (up to $20 \%$ ) are abdominal pain, diarrhea, nausea, and vomiting. These effects are usually mild, transient, and reversible upon lowering the dose (https://www.fda.gov/drugs/postmarketdrug-safety-information-patients-and-providers/colchicinemarketed-colcrys-information).

\section{Discussion}

The anti-inflammatory effects of colchicine are diverse. Colchicine interferes with several inflammatory pathways, including adhesion and recruitment of neutrophils, superoxide production, inflammasome activation, and TNF- $\alpha$ release. The colchicine-tubulin complex effects microtubules that are essential for SARS-CoV-2 entry, transport, and replication.

The ten colchicine studies currently listed on clinicaltrials.gov (https://clinicaltrials.gov/ct2/results? cond $=$ COVID \& term $=$ colchicine $\&$ cntry $=\&$ state $=\&$ city $=$ \&dist=) (Table 1) differ in the timing and dosing of colchicine. These are prospective clinical studies to evaluate colchicine efficacy in COVID-19, but they differ in their outcome measures. Some colchicine COVID-19 clinical trials measure lab results, others time to clinical improvement, whereas others measure the efficacy with respect to clinical status assessed by a 7-point ordinal scale recommended by the World Health Organization (https://www. who.int/blueprint/priority-diseases/key-action/COVID19_Treatment_Trial_Design_Master_Protocol_synopsis_ Final_18022020.pdf).

Consistent with the current understanding of colchicine metabolism, certain drugs, such as lopinavir and ritonavir, used as antiviral drugs for the treatment of COVID-19 infection, increase the potential for colchicine toxicity via modulation of P-gp and CYP3A4 activity. However, only two of the colchicine clinical trials address the use of other medications concomitantly with colchicine, which may warrant a decrease in colchicine dosing. These are important observations for those planning colchicine COVID-19 clinical trials.

This review highlights colchicine's anti-inflammatory and antiviral properties and why colchicine may help patients infected with SARS-CoV-2. We await the results of ten ongoing colchicine clinical trials with COVID-19 patients listed on clinicaltrials.gov. Large, randomized, multicenter, controlled trials are needed to further evaluate the efficacy as well as optimal colchicine dosing and timing for the treatment of COVID-19.

Authors' Contributions All authors take responsibility for the integrity of the review. NS drafted the initial manuscript. NS, BLF, and LB provided critical review and expert context related to colchicine. All authors reviewed and provided input at each step.

\section{Compliance with Ethical Standards}

Conflict of Interest Dr. Schlesinger declares Grants: Pfizer, AMGEN; Advisory boards and consulting: Novartis, Selecta, Mallinckrodt, Horizon Therapeutics, IFM Therapeutics, Johnson and Johnson.

Dr. Brunetti declares: Grants: CSL Behring, Astellas Pharma; Advisory boards and consulting: Horizon Blue Cross Blue Shield of New Jersey.

Dr. Firestein has nothing to declare.

Human and Animal Rights and Informed Consent This article does not contain any studies with human or animal subjects performed by any of the authors. 


\section{References}

1. Weede RP. Poison in the pot: the legacy of Lead Southern Illinois University Press: Carbondale and Edwardsville. 1984;83.

2. Corrodi H, Hardegger E. Die Konfiguration des Colchicins und verwandter Verbindungen Helv. Chem Acta. 1955;38:2030-3.

3. Tardif JC, Kouz S, Waters DD, et al. Efficacy and safety of lowdose colchicine after myocardial infarction. N Engl J Med. 2019;381(26):2497-505.

4. Schlesinger N, Schumacher R, Catton M, et al. Colchicine for acute gout. Cochrane Database Syst Rev. 2006;4:CD006190.

5. Niel E, Scherrmann JM. Colchicine today. Joint Bone Spine. 2006;73:672-8.

6. Bhattacharyya B, Panda D, Gupta S, Banerjee M. Anti-mitotic activity of colchicine and the structural basis for its interaction with tubulin. Med Res Rev. 2008;28:155-83.

7. Andreu JM, Timasheff SN. Tubulin bound to colchicine forms polymers different from microtubules. Proc Natl Acad Sci U S A. 1982;79:6753-6.

8. Borron SW, Scherrmann JM, Baud FJ. Markedly altered colchicine kinetics in a fatal intoxication: examination of contributing factors. Hum Exp Toxicol. 1996;15:885-90.

9. Levy M, Spino M, Read SE. Colchicine: a state-of-the-art review. Pharmacotherapy. 1991;11:196-211.

10. Ben-Chetrit E, Levy M. Colchicine update-1998. Semin Arthritis Rheum. 1998;28:48-59.

11. Phelps R. Appearance of chemotactic activity following intracellular injection of monosodium urate crystals: effect of colchicine. $\mathrm{J}$ Lab Clin Med. 1970;71:622-31.

12. Leung YY, Yao Hui LL, Kraus VB. Colchicine-update on mechanisms of action and therapeutic uses. Semin Arthritis Rheum. 2015;45(3):341-50.

13. Ben-Chetrit E, Levy M. Does the lack of the P-glycoprotein efflux pump in neutrophils explain the efficacy of colchicine in familial Mediterranean fever and other inflammatory diseases? Med Hypotheses. 1998;51:377-80.

14. Cohnheim J. Lectures on general pathology. London: New Sydenham Society; 1882.

15. Niggli V. Signaling to migration in neutrophils: importance of localized pathways. Int J Biochem Cell Biol. 2003;35:1619-38.

16. Cronstein BN, Molad Y, Reibman J, Balakhane E, Levin RI, Weissmann G, et al. Colchicine alters the quantitative and qualitative display of selectins on endothelial cells and neutrophils. J Clin Invest. 1995;96(2):994-1002.

17. Paschke S, Weidner AF, Paust T, Marti O, Beil M, Ben-Chetrit E. Technical advance: inhibition of neutrophil chemotaxis by colchicine is modulated through viscoelastic properties of subcellular compartments. J Leukoc Biol. 2013;94:1091-6.

18. Chia EW, Grainger R, Harper JL. Colchicine suppresses neutrophil superoxide production in a murine model of gouty arthritis: a rationale for use of low-dose colchicine. Br J Pharmacol. 2008;153: 1288-95.

19. Roberge CJ, Gaudry M, Gilbert C, Malawista SE, de Medicis R, Lussier A, et al. Paradoxical effects of colchicine on the activation of human neutrophils by chemotactic factors and inflammatory microcrystal. J Leukoc Biol. 1996;59:864-71.

20. Schroder K, Tschopp J. The inflammasomes. Cell. 2010;140:82132.

21. Guarda G, Zenger M, Yazdi AS, Schroder K, Ferrero I, Menu P, et al. Differential expression of NLRP3 among hematopoietic cells. J Immunol. 2011;186:2529-34.

22. Slobodnick A, Shah B, Krasnokutsky S, Pillinger MH. Update on colchicine, 2017. Rheumatology (Oxford). 2018;57:i4-i11.

23. Misawa T, Takahama M, Kozaki T, Lee H, Zou J, Saitoh T, et al. Microtubule-driven spatial arrangement of mitochondria promotes activation of the NLRP3 inflammasome. Nat Immunol. 2013;14: 454-60.

24. Dalbeth N, Lauterio TJ, Wolfe HR. Mechanism of action of colchicine in the treatment of gout. Clin Ther. 2014;36(10):1465-79.

25. Robertson S, Martinez GJ, Payet CA, Barraclough JY, Celermajer DS, Bursill C, et al. Colchicine therapy in acute coronary syndrome patients acts on caspase-1 to suppress nlrp3 inflammasome monocyte activation. Clin Sci. 2016;130:1237-46.

26. Martinez GJ, Robertson S, Barraclough J, Xia Q, Mallat Z, Bursill $\mathrm{C}$, et al. Colchicine acutely suppresses local cardiac production of inflammatory cytokines in patients with an acute coronary syndrome. J Am Heart Assoc. 2015;4(8):e002128.

27. Fujisue K, Sugamura K, Kurokawa H, Matsubara J, Ishii M, Izumiya $\mathrm{Y}$, et al. Colchicine improves survival, left ventricular remodeling, and chronic cardiac function after acute myocardial infarction. Circ J. 2017;81:1174-82.

28. Ding AH, Porteu F, Sanchez E, Nathan CF. Down-regulation of tumor necrosis factor receptors on macrophages and endothelial cells by microtubule depolarizing agents. J Exp Med. 1990;171: 715-27.

29. Li Z, Davis GS, Mohr C. Inhibition of LPS-induced tumor necrosis factor- $\alpha$ production by colchicine and other microtubules disrupting drugs. Immunobiology. 1996;195:624-9.

30. Jackman RW, Rhoads MG, Cornwell E, Kandarian SC. Microtubule-mediated NF-kappaB activation in the TNF-alpha signaling pathway. Exp Cell Res. 2009;315:3242-9.

31. Greber U. Signaling in viral entry. CMLS Cell Mol Life Sci. 2002;59:608-26.

32. Richter M, Boldescu V, Graf D, Streicher F, Dimoglo A, Bartenschlager R, et al. Synthesis, biological evaluation, and molecular docking of combretastatin and colchicine derivatives and their hCE1-activated prodrugs as anti-viral agents. ChemMedChem. 2019;14:469-83.

33. Biswas K, Das Sarma J. Effect of microtubule disruption on neuronal spread and replication of demyelinating and nondemyelinating strains of mouse hepatitis virus in vitro. J Virol. 2014;88:3043-79.

34. Lu N, Yang Y, Liu H, Ding X, Ou Y, Xia J, et al. Inhibition of respiratory syncytial virus replication and suppression of RSVinduced airway inflammation in neonatal rats by colchicine. Biotechnology. 2019;9:392.

35. Worachartcheewan A, Songtawee N, Siriwong S, Prachayasittikul S, Nantasenamat C, Prachayasittikul V. Rational design of colchicine derivatives as anti-HIV agents via QSAR and molecular docking. Med Chem. 2019;15:328-40.

36. Sawicki SG, Sawicki DL, Siddell SG. A contemporary view of coronavirus transcription. J Virol. 2007;81:20-9.

37. Weiss SR, Navas-Martin S. Coronavirus pathogenesis and the emerging pathogen severe acute respiratory syndrome coronavirus. Microbiol Mol Biol Rev. 2005;69(4):635-64.

38. Sims AC, Burkett SE, Yount B, Pickles RJ. SARS-CoV replication and pathogenesis in an in vitro model of the human conducting airway epithelium. Virus Res. 2008;133(1):33-44.

39. de Haan CA, Rottier PJ. Molecular interactions in the assembly of coronaviruses. Adv Virus Res. 2005;64:165-230.

40. Milewska A, Nowak P, Owczarek K, Szczepanski A, Zarebski M, Hoang A, et al. Entry of human coronavirus NL63 into the cell. J Virol. 2018;92(3):e01933-17.

41. Ozdemir R, Ozdemir R, Yurttutan S, Oncel MY, Uysal B, Unverdi $\mathrm{HG}$, et al. Colchicine protects against hyperoxic lung injury in neonatal rats. Neonatology. 2012;102:265-9.

42. Tschöpe C, Cooper LT, Torre-Amione G, Van Linthout S. Management of myocarditis-related cardiomyopathy in adults. Circ Res. 2019;124:1568-83. 
43. Ito $\mathrm{M}$, Yanagi $\mathrm{Y}$, Ichinohe $\mathrm{T}$. Encephalomyocarditis virus viroporin 2B activates NLRP3 inflammasome. PLoS Pathog. 2012;8(8): e1002857.

44. Grailer JJ, Canning BA, Kalbitz M, Haggadone MD, Dhond RM, Andjelkovic AV, et al. Critical role for the NLRP3 inflammasome during acute lung injury. J Immunol. 2014;192(12):5974-83.

45. Gandolfini I, Delsante M, Fiaccadori E, Zaza G, Manenti L, Degli Antoni A, et al. COVID-19 in kidney transplant recipients. Am J Transplant. 2020. https://doi.org/10.1111/ajt.15891.
46. Schlesinger N. Reassessing the safety of intravenous and compounded injectable colchicine in acute gout treatment. Expert Opin Drug Saf. 2007;6(6):625-9.

Publisher's Note Springer Nature remains neutral with regard to jurisdictional claims in published maps and institutional affiliations. 